and less liable to disintegration from atmospheric influences. It appears highly probable, from the aspect presented in our immediate neighbourhood, and eastward, that the Bunter formation had been considerably upheaved and subjected to great denudation previous to the deposition of the Keuper ; for it did not appear that the Bunter - which was 650 feet thick-was found on any of the promontories north of the Mersey; it was seen only on the low-lying plains from Widnes to Warrington, and along the river-valley eastward; and at Hill Cliff, where the lower beds of the Keuper are quarried for building purposes, they appear to lie unconformably upon the pebblebeds of the Bunter series. After making some remarks on the Lower Keuper, he concluded by referring to the forms of life which presented themselves during the New Red Sandstone epoch.

Mr. Paterson exhibited a geological section of the country from Weston Point to Halton.

The President expressed, on behalf of the Society, his warmest thanks to Mr. Paterson for the paper he had read.

The Rers. W. Hamilton, J. D. Massingham, and R. R. Moore addressed the meeting; and after a vote of thanks to the Chairman, the Members separated.-Warrington Guardian, May 13.

\title{
OORRESPONDENCE.
}

\section{ORIGIN OF ROCK-BASINS IN NEW ZEALAND.}

To the Editor of the Geological Magazine.

Sir,-As I had erroneously been led to believe that my eminent friend Dr. Hector, who conducts the Geological Survey in the southern portion of New Zealand, had adopted the same view as Dr. Haast respecting the power of Glaciers to excavate basins in hard rocks, I now transmit a letter I have recently received from him, which shows that his opinion is very different indeed to that which has been attributed to him. In fact, the views of Dr. Hector seem to coincide with those of the geologists who, like myself, refer in great measure the formation of valleys and lake-cavities to ancient plications and ruptures of the strata-doubtless deepened in mountainous countries, whether by ice or water. - Your obedient servant, July 14, 1865 .

Roderick I. Murchison.

Dear Sir Roderick, - I feel greatly obliged to you for the trouble you took in laying the notes on our Geology before the Society, and for your kind expressions respecting my labours. It is only lately that $I$ have been able to settle down to work up the materials $I$ have amassed, so that there are many points only now becoming clear to my mind.

I am afraid that, with respect to the Glacier-erosion of valleys, you are confusing my views with those of Haast. I cannot at all agree with him, as to the power he attributes to Glaciers, of excavating the floors of their valleys, so as to form rock-basins, 
unless it can be shown that they are advancing with the dip of soft-bedded strata which flank the harder rocks that form the mountains.

I believe that instances of this kind have occurred in New Zealand, especially on the west side of the mountains.

The great valleys, however, which exist in the Crystalline rocks, and which are 'rock-basins,' have become so by unequal axial motion, which, in the case of Otago, has generally been a subsidence of the mountain-centres, more rapid on the west than the east, and accompanied by a rise of the flanking formation. However, I can have no doubt that in the schistose formations, and other stratified rocks having alternations of hard and soft beds, the valleys have been excavated in the strike of the soft strata by simple erosion.

In the case of the massive Crystalline rocks, I have reason to suppose that the valleys, such as are occupied by the true coastsounds, have originally followed lines of injected basic rocks, that invaded the crystalline mass subsequent to its original metamorplism, and which basic rocks, decomposing more freely than the gueissic group on the subsequent elevation of the land, gave way before the descending ice. It seems to me that the essential condition to the existence of glaciers is a lofty plateau, or slightly inclined mountaintop, on which the snow rests in sufficient quantity to descend into the lower levels as its only means of escape. The greatest erosion takes place where it descends over the edge of this plateau, or 'breeding-ground;' and if there is a soft 'run' in the rocks, it must cut a notch there which will extend into the higher country as a deep valley. I believe I can prove that it has been thus that all our principal valleys have been formed. Ice is only, after all, one of the ordinary destructive forces, the effect of which has, perhaps, been rather underrated; but there has been no new erosive agency added to that formerly known to geologists. The ice-fall acts just like a great cascade in a river, at which point the greatest erosion goes on-that which is effected by the gently running part of the stream being small. The only supposed new point in these discoveries is the excavation, or ploughing action, by the ice of the glacier after it has descended to the valley-level, and with that $I$ certainly do not agree.

Trusting that I can shortly support my views with full details, I remain, my dear Sir Roderick, yours sincerely,

Dunedin: Aprit 18, 1865.

Janes Hector.

\section{GEOLOGY OF MATLOCK AND THE NEIGHBOURHOOD.}

To the Editor of the Geological Magazine.

Sir,-Allow me, through the medium of your Magazine, to direct the attention of Geological tourists during the ensuing autumn to some interesting spots in a part of Derbyshire not yet sufficiently known. The Mountain-limestone around Matlock presents very instructive sections, which have lately been extended by quarrying. 